\title{
Essential Oils Extracted from Different Species of the Lamiaceae Plant Family as Prospective Bioagents against Several Detrimental Pests
}

\author{
Asgar Ebadollahi ${ }^{1, *(\mathbb{C})}$, Masumeh Ziaee ${ }^{2}$ and Franco Palla ${ }^{3, *}$ \\ 1 Moghan College of Agriculture and Natural Resources, University of Mohaghegh Ardabili, Ardabil \\ 56199-36514, Iran \\ 2 Department of Plant Protection, Faculty of Agriculture, Shahid Chamran University of Ahvaz, Ahvaz \\ 61357-43311, Iran; m.ziaee@scu.ac.ir \\ 3 Department of Biological, Chemical and Pharmaceutical Sciences and Technologies, University of Palermo, \\ Palermo 38-90123, Italy \\ * Correspondence: ebadollahi@uma.ac.ir (A.E.); franco.palla@unipa.it (F.P.)
}

Academic Editors: Carmen Formisano, Vincenzo De Feo and Filomena Nazzaro Received: 5 March 2020; Accepted: 27 March 2020; Published: 28 March 2020

check for updates

\begin{abstract}
On the basis of the side effects of detrimental synthetic chemicals, introducing healthy, available, and effective bioagents for pest management is critical. Due to this circumstance, several studies have been conducted that evaluate the pesticidal potency of plant-derived essential oils. This review presents the pesticidal efficiency of essential oils isolated from different genera of the Lamiaceae family including Agastache Gronovius, Hyptis Jacquin, Lavandula L., Lepechinia Willdenow, Mentha L., Melissa L., Ocimum L., Origanum L., Perilla L., Perovskia Kar., Phlomis L., Rosmarinus L., Salvia L., Satureja L., Teucrium L., Thymus L., Zataria Boissier, and Zhumeria Rech. Along with acute toxicity, the sublethal effects were illustrated such as repellency, antifeedant activity, and adverse effects on the protein, lipid, and carbohydrate contents, and on the esterase and glutathione S-transferase enzymes. Chemical profiles of the introduced essential oils and the pesticidal effects of their main components have also been documented including terpenes (hydrocarbon monoterpene, monoterpenoid, hydrocarbon sesquiterpene, and sesquiterpenoid) and aliphatic phenylpropanoid. Consequently, the essential oils of the Lamiaceae plant family and their main components, especially monoterpenoid ones with several bioeffects and multiple modes of action against different groups of damaging insects and mites, are considered to be safe, available, and efficient alternatives to the harmful synthetic pesticides.
\end{abstract}

Keywords: essential oil; Lamiaceae; acute toxicity; sublethal effects; monoterpenoids

\section{Introduction}

Synthetic chemicals such as carbamates, pyrethroids, organochlorines, and organophosphates have played a principal role in the plant protection strategies against agroindustrial and medicinal arthropod pests within the past and present century. However, there are public concerns all over the world about the negative side effects of detrimental chemicals such as residues on food and in drinking water, acute or chronic toxicity to humans and other non-target organisms, outbreaks of secondary pests by abolishing their natural enemies, and the emergence of pest resistance [1-3]. Accordingly, there is an imperative demand to diminish chemical pesticides and reveal safe and potential alternatives.

In recent years, the utilization of biopesticides in pest management has been progressing. Three categories of biopesticides have been identified by the United State Environmental Protection Agency as follows: biochemical biopesticides such as botanical pesticides and other natural compounds, 
plant-incorporated protectants such as transgenic Bt toxin, and biocontrol organisms such as microbial fungi and parasitoid wasps [4]. Plants create secondary metabolites which include numerous aromatic compounds against different herbivores. They are considered to be attractants to pests' antagonists and they can even be used by the plants to attract pollinators [5]. There are almost 17,500 aromatic plant species which are important for pesticidal approaches [6]. There is also ongoing progress in the search for pesticidal effects of essential oils extracted from different plant species for pest management strategies [7-11]. Furthermore, essential oils have been assayed as alternatives to commercial pesticides for the green conservation of cultural assets [12,13].

Although the susceptibility of many detrimental insects and mites to the essential oils extracted from different plant families has been documented, there are considerably many more reports on the high pesticidal potential of diverse species in the Lamiaceae family [14-16]. Therefore, the main objectives of this present study were to collect and review quality references in the field of pesticidal properties of essential oils extracted from the Lamiaceae plant family and to focus more on using natural agents to control harmful arthropods. This review was accumulated from journals indexed in major databases including Scopus, Web of Science, PubMed, and Google Scholar with separated and combined keywords of essential oil, Lamiaceae, toxicity, and lethal and sublethal effects.

\section{Plant Essential Oils and Their Pesticidal Activities}

Plant essential oils, which are the principal reason for the odors of aromatic plants, are complex mixtures of terpenic (especially mono- and sesquiterpenes and mono- and sesquiterpenoids), aromatic, and aliphatic components with about 24 to $48 \mathrm{~h}$ half-lives, and are non-persistent in the environment [6,17]. The chemical composition of essential oils is affected by different endogenous and exogenous factors, for example, plant species, geographical position, climate conditions, harvesting time, and extraction method [18-21]. Plant essential oils or their volatile components cause critical defense strategies against herbivorous pests. They also have a vigorous role in plant-plant interactions and attraction of pollinators [22,23]. The environmental safety of essential oils is the main reason for their production in bulk quantities and their wide application in agriculture, cosmetic, and medical industries, and recently, in sustainable conservation of cultural assets [12,24,25]. Because of the natural origin of these secondary metabolites, they are degraded easily by natural degradation mechanisms [26]. Furthermore, apart from some exceptions, essential oils have not shown any toxicity to the homoeothermic animals and they are considered to be "generally recognized as safe" by the Environmental Protection Agency and Food and Drug Administration in the USA [27].

Essential oils exhibit a wide spectrum of pesticidal activities from lethal to sublethal effects against a wide range of insects and mites $[7,24,28]$. Pesticidal effects of essential oils extracted from different plant families such as Apiaceae, Asteraceae, Chenopodiaceae, Cupressaceae, Lamiaceae, Lauraceae, Myrtaceae, Zingiberaceae, Umbelliferae, and Geraniaceae have been documented [7,9,29,30]. Indeed, scientific attention to the application of essential oils for pest management strategies has witnessed progressive growth, in recent years [8]. Essential oils are biodegradable, commonly safe to mammals, and available agents [24]. Given that they are mixers of diverse components, various modes of action from acute toxicity to repellency, antinutritional and developmental inhibitory effects, and the impact on neural and biochemical processes have been recorded for them [16,26,31]. Therefore, there is slight change of pests' resistance to these botanical volatiles [32], and it can be concluded that these plant-derived volatiles are eco-friendly and effective alternatives to the detrimental synthetic pesticides.

\section{Lamiaceae Plant Family with Potential Pesticidal Oils}

The Lamiaceae or mint family with a wide distribution in different natural ecosystems comprises 236 genera and about 6000 species [33]. These aromatic plants have square stems in cross-section, opposite leaves, zygomorphic flowers with five united petals and sepals, and they are cultivated because of their easy propagation, i.e., stem cutting [34]. Many species from the Lamiaceae family possess high quality essential oils in all aboveground parts, especially in leaves and flowers, and are distinguished 
in applications for medicinal purposes with effective antibacterial, antifungal, antioxidant, antiviral, and even anticancer properties, as well as in the cosmetic and perfumery industries [35-37].

The search in large scientific databases including Scopus, Web of Science, PubMed, and Google Scholar displayed that Plant genera of the family Lamiaceae including Agastache, Hyptis, Lavandula, Lepechinia, Mentha, Melissa, Ocimum, Origanum, Perilla, Perovskia, Phlomis, Rosmarinus, Salvia, Satureja, Teucrium, Thymus, Zataria, and Zhumeria have great potential in pest management strategies. According to Table 1, pesticidal effects of the essential oils isolated from these plants can be expressed by lethal (acute toxicity) to sublethal (chronic effects) approaches including repellent and antifeedant activities, and adverse effects on the energy content and digestive enzymes or the enzymes that are effective in electron transport. According to the many reports on the insecticidal and acaricidal activities, Lavandula, Mentha, Ocimum, Origanum, Satureja, and Thymus species are among the most promising plants in detrimental pest management [38-47].

Table 1. A list of reports indicating pesticidal effects of essential oils isolated from the Lamiaceae family.

\begin{tabular}{|c|c|c|}
\hline Genera & Species & Lethal/SubLethal Effects and Targeted Arthropod Pests \\
\hline Agastache Gronovius & A. foeniculum (Pursh) Kuntze & Fumigant toxicity against T. castaneum and R. dominica [42]. \\
\hline \multirow{3}{*}{ Hyptis Jacquin } & H. spicigera Lamarck & Repellency against $S$. zeamais [43]. \\
\hline & H. suaveolens (L.) Poit & Repellency against $S$. zeamais [43]. \\
\hline & L. angustifolia Miller & Contact and fumigant toxicity against T. urticae [44]. \\
\hline \multirow[t]{2}{*}{ Lavandula L. } & $\begin{array}{l}\text { L. hybrida Reverchon } \\
\text { L. luisieri (Rozeira) Rozeira }\end{array}$ & $\begin{array}{l}\text { Repellency against } S \text {. zeamais, C. pusillus, and Tenebrio molitor [42] } \\
\text { Antifeedant effects against L. decemlineata [43]. }\end{array}$ \\
\hline & L. stoechas L. & $\begin{array}{c}\text { Fumigant toxicity against T. castaneum, L. serricorne, and } R . \\
\text { dominica [47]. }\end{array}$ \\
\hline \multirow[t]{3}{*}{ Lepechinia Willdenow } & L. betonicifolia (Lam.) Epling & Repellency against T. castaneum [48]. \\
\hline & M. arvensis L. & Acaricidal effects on D. farinae and D. pteronyssinus [49]. \\
\hline & M. longifolia (L.) L. & Larvicidal activity against $C$. pipiens $[50]$. \\
\hline \multirow[t]{5}{*}{ Mentha L. } & M. microphylla Koch & $\begin{array}{l}\text { Contact and fumigant toxicity against T. castaneum and S. oryzae } \\
\text { [51]. }\end{array}$ \\
\hline & M. piprita L. & Toxicity on the adult females of $A$. gossypii [52]. \\
\hline & M. pulegium $\mathrm{L}$. & Toxicity on the adult females of A. gossypii [52]. \\
\hline & M. spicata L. & Larvicidal activity against C. pipiens [50]. \\
\hline & M. suaveolens Ehrh. & Larvicidal activity against C. pipiens [50]. \\
\hline Melissa L. & $\begin{array}{l}\text { M. officinalis L. } \\
\text { O. americanum L. }\end{array}$ & $\begin{array}{l}\text { Fumigant toxicity and antifeedant effect against T. castaneum [53] } \\
\text { Toxicity and repellency against S. zeamais [54]. }\end{array}$ \\
\hline \multirow[t]{4}{*}{ Ocimum L. } & $\begin{array}{l}\text { O. basilicum } \mathrm{L} \text {. } \\
\text { O. gratissimum } \mathrm{L} \text {. }\end{array}$ & $\begin{array}{l}\text { Contact and fumigant toxicity against T. putrescentiae [55]. } \\
\text { Larvicidal activity against C. quinquefasciatus [56]. }\end{array}$ \\
\hline & O. sanctum L. & Larvicidal activity against C. quinquefasciatus [56]. \\
\hline & O. acutidens Ietswaart & Toxicity effects on adults of Bruchus dentipes [57]. \\
\hline & O. elongatum E. \& M. & Acaricidal activity against $V$. destructor [58]. \\
\hline \multirow{4}{*}{ Origanum L. } & O. glandulosum Desf. & Contact and fumigant toxicities against $R$. dominica [59]. \\
\hline & O. onites $L$. & $\begin{array}{c}\text { Contact and fumigant toxicity against } R \text {. dominica, T. confusum, } S . \\
\text { granarius, and } S \text {. oryzae [60]. }\end{array}$ \\
\hline & O. rotundifolium Boiss. & Fumigant toxicity against $S$. granaries adults [61]. \\
\hline & O. vulgare $\mathrm{L}$. & Exposure to volatile compounds against A. punctatum [13]. \\
\hline Perilla L. & P. frutescens (L.) Britton & Insecticidal and repellent activities against L. serricorne [62]. \\
\hline Perovskia Kar. & P. atriplicifolia Benth. & Fumigant toxicity against S. oryzae and T. castaneum adults [63]. \\
\hline Phlomis L. & P. umbrosa Turcz. & Contact and fumigant toxicity on S. zeamais and T. castaneum [64]. \\
\hline \multirow[t]{4}{*}{ Rosmarinus L. } & R. officinalis L. & $\begin{array}{l}\text { Contact and fumigant toxicity, and repellency effects against } S \text {. } \\
\text { longipalpa [65]. }\end{array}$ \\
\hline & S. fruticosa Mill. & Larvicidal activity against C. pipiens [50]. \\
\hline & S. hydrangea Dc. & Fumigant toxicity against $S$. granaries adults [61]. \\
\hline & Salvia apiana Jeps. & $\begin{array}{l}\text { Deterrent and larvicidal activity on } A . \text { aegypti and } A . \\
\text { quadrimaculatus [66]. }\end{array}$ \\
\hline \multirow[t]{6}{*}{ Salvia L. } & Salvia elegans Vahl & $\begin{array}{l}\text { Deterrent and larvicidal activity on } A \text {. aegypti and } A . \\
\text { quadrimaculatus [66]. }\end{array}$ \\
\hline & Salvia leucantha Cav. & $\begin{array}{l}\text { Deterrent and larvicidal activity on } A \text {. aegypti and } A . \\
\text { quadrimaculatus [66]. }\end{array}$ \\
\hline & S. multicaulis Vahl. & Fumigant toxicity against adults of $S$. granaries [61]. \\
\hline & S. numerosa L. & Fumigant toxicity against adults of $S$. granaries [61]. \\
\hline & S. officialis L. & $\begin{array}{l}\text { Deterrent and larvicidal activity on } A \text {. aegypti and } A . \\
\text { quadrimaculatus [66]. }\end{array}$ \\
\hline & S. pomifera Hayek & Larvicidal activity against $C$. pipiens [50]. \\
\hline
\end{tabular}


Table 1. Cont

\begin{tabular}{|c|c|c|}
\hline Genera & Species & Lethal/SubLethal Effects and Targeted Arthropod Pests \\
\hline \multirow{6}{*}{ Satureja L. } & S. pratensis L. & $\begin{array}{l}\text { Contact and fumigant toxicity against } T \text {. castaneum and } C . \\
\text { maculatus [67]. }\end{array}$ \\
\hline & S. sclarea L. & Fumigant toxicity against adults of $S$. granaries [61]. \\
\hline & S. hortensis L. & Contact and fumigant toxicity against T. urticae [68]. \\
\hline & S. khuzistanica Jamzad & Antifeedant activity and toxicity to L. decemlineata [69]. \\
\hline & S. spicigera Boiss. & Fumigant toxicity against adults of $S$. granaries [61]. \\
\hline & S. thymbra L. & $\begin{array}{l}\text { Fumigant toxicity against E. kuehniella, P. interpunctella and } A . \\
\text { obtectus [70]. }\end{array}$ \\
\hline \multirow[t]{4}{*}{ Teucrium L. } & T. polium L. & Contact and fumigant toxicity against T. urticae [68]. \\
\hline & T. daenensis Celak & Antifeedant activity and toxicity to L. decemlineata [69]. \\
\hline & T. eriocalyx (Ronniger) Jalas & Contact and fumigant toxicity against T. urticae [71]. \\
\hline & T. fallax Fisch. \& Mey. & Fumigant toxicity against adults of $S$. granaries [61]. \\
\hline \multirow{3}{*}{ Thymus L. } & T. kotschyanus Boiss. & Contact and fumigant toxicity against T. urticae [71]. \\
\hline & $\begin{array}{l}\text { T. persicus (Ronniger ex Rech.f.) } \\
\text { Jalas }\end{array}$ & Fumigant toxicity against adults of T. castaneum and S. oryzae [69]. \\
\hline & $\begin{array}{l}\text { T. satureioides C. \& B. } \\
\text { T. sipyleus Boiss. } \\
\text { T. vulgaris L. }\end{array}$ & $\begin{array}{c}\text { Acaricidal activity against } V \text {. destructor [58]. } \\
\text { Fumigant toxicity against adults of S. granaries [61]. } \\
\text { Exposure to volatile compounds against } A \text {. punctatum [42]. }\end{array}$ \\
\hline Zataria Boissier & Z. multiflora Boiss. & $\begin{array}{l}\text { Fumigant toxicity on adults of } T \text {. castaneum, S. granarius and C. } \\
\text { maculatus [72]. }\end{array}$ \\
\hline Zhumeria Rech. & Z. majdae Rech. & $\begin{array}{l}\text { Adverse effect on protein, lipid and carbohydrate contents and on } \\
\text { esterase and glutathione S-transferase enzymes' activities of } T . \\
\text { castaneum larvae [73]. }\end{array}$ \\
\hline
\end{tabular}

The full scientific names of mentioned pests are as follows: Acanthoscelides obtectus Say (Coleoptera: Chrysomelidae), Aedes aegypti L. (Diptera: Culicidae), Anobium punctatum de Geer (Coleoptera: Anobidae), Anopheles dirus Peyton \& Harrison (Diptera: Culicidae), Anopheles quadrimaculatus Say (Diptera: Culicidae), Aphis gossypii Glover (Hemiptera: Aphididae), Brevicoryne brassicae L. (Hemiptera: Aphididae), Bruchus dentipes Baudi (Coleoptera: Chrysomelidae), Callosobruchus maculatus (F.) (Coleoptera: Chrysomelidae), Culex quinquefasciatus Say. (Diptera: Culicidae), Culex pipiens L. (Diptera: Culicidae), Cryptolestes pusillus (Schöenherr) (Coleoptera: Laemophloeidae), Dermatophagoides farinae Hughes (Acari: Pyroglyphidae), Dermatophagoides pteronyssinus (Trouessart) (Acari: Pyroglyphidae), Ephestia kuehniella Zeller (Lepidoptera: Pyralidae), Lasioderma serricorne F. (Coleoptera: Anobiidae), Leptinotarsa decemlineata (Say) (Coleoptera: Chrysomelidae), Musca domestica L. (Diptera: Muscidae), Plodia interpunctella Hübner (Lepidoptera: Pyralidae), Rhyzopertha dominica (F.) (Coleoptera: Bostrichidae), Sitophilus granarius (L.) (Coleoptera: Curculionidae), Sitophilus oryzae (L.) (Coleoptera: Curculionidae), Sitophilus zeamais Motschulsky (Coleoptera: Curculionidae), Supella longipalpa (Fabricius) (Blattaria: Ectobiidae), Tenebrio molitor L. (Coleoptera: Tenebrionidae), Tetranychus urticae Koch (Acari: Tetranychidae), Tribolium castaneum Herbst (Coleoptera: Tenebrionidae), Tyrophagus putrescentiae (Schrank) (Sarcoptiformes: Acaridae) and Varroa destructor Anderson \& Trueman (Acari: Varroidae).

\section{Chemical Composition of Essential Oils and Their Relative Pesticidal Effects}

On the basis of the total percentage, the main two to four components of the introduced Lamiaceae essential oils are displayed in Table 2. Some of these components such as 1,8-cineole, borneol, camphor, carvacrol, caryophyllene, linalool, terpinene, thymol, $\alpha$-pinene, $\beta$-pinene, and $\varrho$-cymene were identified in most of the species. For example, 1,8-cineole was introduced as one of the main components of Agastache foeniculum (Pursh) Kuntze, Lavandula angustifolia Miller, Lavandula hybrida Briq., Lavandula luisieri (Rozeira) Rozeira, Mentha microphylla C. Kock, Mentha spicata L., Perovskia atriplicifolia Benth., Rosmarinus officinalis L., Salvia apiana Jepson, Salvia multicaulis Vahl., Salvia pratensis L., and Satureja hortensis L. essential oils. In contrast, some others were found as main components in the unique species. Sclareol, for instance, was reported as a major component only in the Salvia sclarea L. essential oil (Table 2). 
Table 2. Main components of the essential oils isolated from different species of the Lamiaceae plant family with pesticidal prominence.

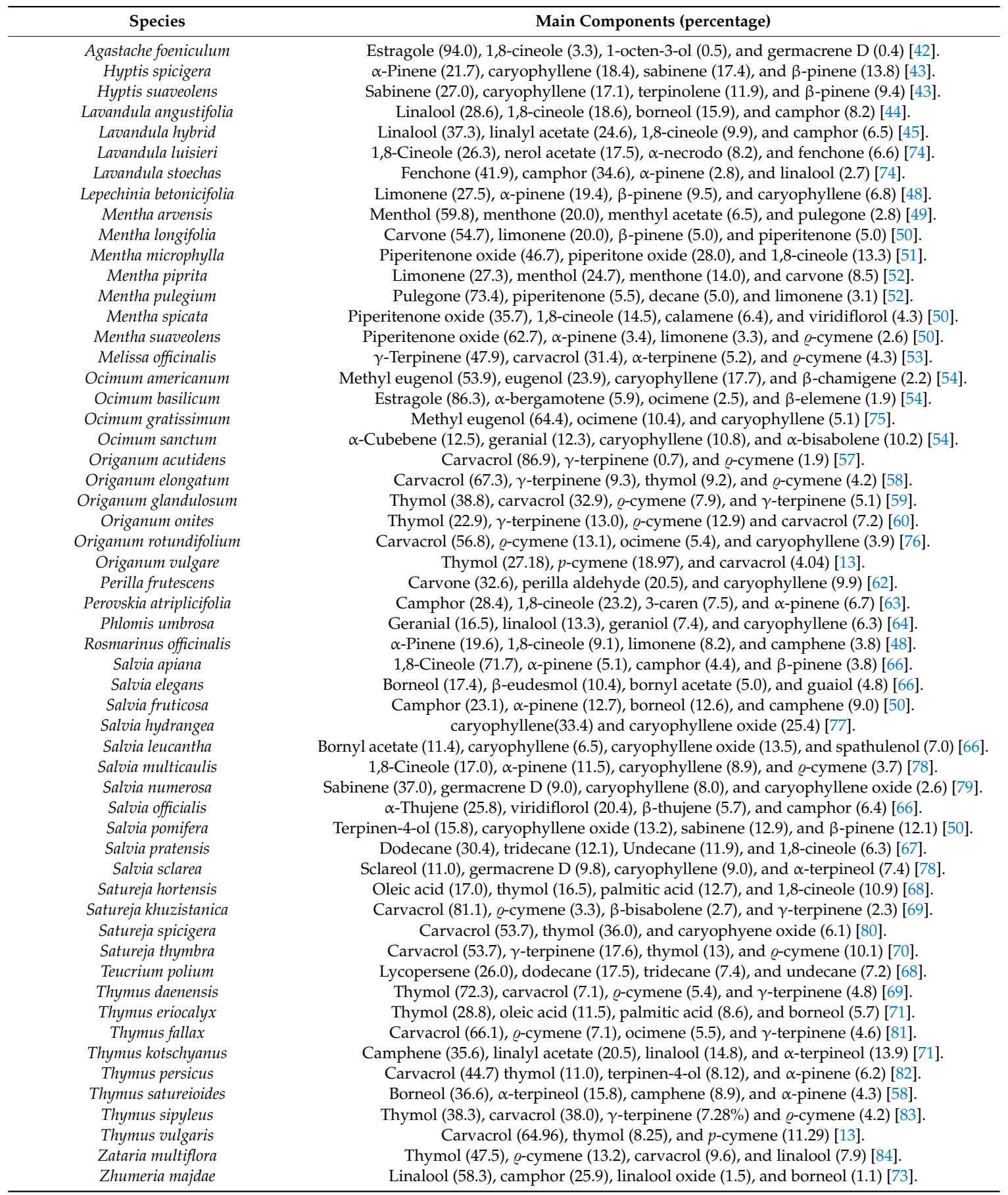

Terpenes which are large and diverse natural hydrocarbons are commonly classified according to the number of isoprene units $\mathrm{C}_{5} \mathrm{H}_{8}$, to hemi- (one unit), mono- (two units), sesqui- (three units), di- (four units), ses- (five units), tri- (six units), tetra- (8 units), and polyterpenes (n units) [85]. Although the majority of these compounds are found in plant essential oils, the more complex terpenes, such as lanosterol, exist in animals. Furthermore, each terpene can be oxygenated and modified to terpenoid hydrocarbons [86,87]. In general, there are high amount of terpenes in the essential oils of the Lamiaceae family. The main components in the essential oils of the Lamiaceae plants from acyclic, cyclic, and bicyclic monoterpenes; monoterpenoids; sesquiterpenes; sesquiterpenoids; and 
phenylpropanes' groups [88] possess promising pesticidal properties against several arthropod pests (Table 3 and Figure 1).

Table 3. Classification and pesticidal effects of main components reported in the essential oils of the Lamiaceae plant family.

\begin{tabular}{|c|c|c|}
\hline Components & Classification & Pesticidal Effects \\
\hline 1,8-Cineole & Bicyclic monoterpenoid & Larvicidal and pupicidal activity against C. quinquefasciatus [89]. \\
\hline 3-Carene & Bicyclic monoterpene & Toxicity against the adults of S. zeamais [90]. \\
\hline Borneol & Bicyclic monoterpenoid & Larvicidal and pupicidal activity against C. quinquefasciatus [89]. \\
\hline Bornyl acetate & Bicyclic monoterpenoid & Fumigant toxicity against the adults of $S$. granaries [91]. \\
\hline Camphene & Bicyclic monoterpene & Toxicity on P. xylostella larvae [92]. \\
\hline Camphor & Bicyclic monoterpenoid & Larvicidal and pupicidal activity against C. quinquefasciatus [89]. \\
\hline Carvacrol & Cyclic monoterpenoid & Contact and fumigant toxicity against the adults of C. lectularius [93]. \\
\hline Carvone & Cyclic monoterpenoid & Toxicity against the adults of S. zeamais [90]. \\
\hline Caryophyllene & Bicyclic sesquiterpene & Insecticidal activities against $S$. frugiperda larvae and pupae [94]. \\
\hline Caryophyllene oxide & Bicyclic sesquiterpenoid & Insecticidal activities against $S$. frugiperda larvae and pupae [94]. \\
\hline Estragole & Cyclic phenylpropanoid & $\begin{array}{l}\text { Fumigant toxicity and acetylcholine esterase inhibition against } B . \\
\text { germanica [95]. }\end{array}$ \\
\hline Eugenol & Cyclic phenylpropanoid & Contact toxicity against the adults of T. castaneum [96]. \\
\hline Fenchone & Bicyclic monoterpenoid & Fumigant toxicity against the adults of $S$. granaries [91]. \\
\hline Geranial & Acyclic monoterpenoid & Larvicidal and pupicidal activity against C. quinquefasciatus [89]. \\
\hline Geraniol & Acyclic monoterpenoid & Contact and fumigant toxicity against the adults of C. lectularius [93]. \\
\hline Geranyl acetate & Acyclic monoterpenoid & Fumigant toxicity against the adults of $S$. granaries [91]. \\
\hline Germacrene D & Cyclic sesquiterpene & Larvicidal and pupicidal activity against C. quinquefasciatus [89]. \\
\hline Guaiol & Bicyclic sesquiterpenoid & Fumigant toxicity against the adults of $S$. granaries [91]. \\
\hline Limonene & Cyclic monoterpene & Toxicity against the adults of S. zeamais [90]. \\
\hline Linalool & Acyclic monoterpenoid & Toxicity on P. xylostella larvae [92]. \\
\hline Linalool oxide & Cyclic monoterpenoid & Toxicity on P. xylostella larvae [92]. \\
\hline Linalyl acetate & Acyclic monoterpenoid & Fumigant toxicity against the adults of $S$. granaries [91]. \\
\hline Menthol & Cyclic monoterpenoid & Fumigant toxicity against the adults of $S$. granaries [91]. \\
\hline Menthone & Cyclic monoterpenoid & Contact and fumigant toxicity against the adults of C. lectularius [93]. \\
\hline Menthyl acetate & Cyclic monoterpenoid & $\begin{array}{l}\text { Fumigant toxicity and repellent activity on first-instar nymphs of } R \text {. } \\
\text { prolixus [97]. }\end{array}$ \\
\hline Nerol acetate & Acyclic monoterpenoid & Fumigant toxicity against the adults of $S$. granaries [91]. \\
\hline Ocimene & Acyclic monoterpene & $\begin{array}{l}\text { Fumigant toxicity and acetylcholine esterase inhibition against } B . \\
\text { germanica [95]. }\end{array}$ \\
\hline Perillaldehyde & Cyclic monoterpenoid & Larvicidal and pupicidal activity against C. quinquefasciatus [89]. \\
\hline Piperitenone & Cyclic monoterpenoid & Larvicidal and pupicidal activity against C. quinquefasciatus [89]. \\
\hline Piperitenone oxide & Cyclic monoterpenoid & $\begin{array}{l}\text { Larvicidal, ovicidal, oviposition-deterrent, and repellent effect against } \\
\text { A. stephensi [98]. }\end{array}$ \\
\hline Pulegone & Cyclic monoterpenoid & Larvicidal and pupicidal activity against C. quinquefasciatus [89]. \\
\hline Sabinene & Bicyclic monoterpene & Larvicidal and pupicidal activity against C. quinquefasciatus [89]. \\
\hline Terpinen-4-ol & Cyclic monoterpenoid & Contact and fumigant toxicity against C. lectularius adults [93]. \\
\hline Terpinolene & Cyclic monoterpene & Larvicidal and pupicidal activity against C. quinquefasciatus [89]. \\
\hline Thujene & Bicyclic monoterpene & $\begin{array}{l}\text { Fumigant toxicity and acetylcholine esterase inhibition against } B . \\
\text { germanica [89]. }\end{array}$ \\
\hline Thymol & Cyclic monoterpenoid & Fumigant toxicity against the adults of $S$. granaries [91]. \\
\hline$\alpha$-Pinene & Bicyclic monoterpene & $\begin{array}{l}\text { Fumigant and contact toxicities and repellency against T. castaneum } \\
\text { adults [96]. }\end{array}$ \\
\hline$\alpha$-Terpinene & Cyclic monoterpene & Larvicidal and pupicidal activity against C. quinquefasciatus [89]. \\
\hline$\alpha$-Terpineol & Cyclic monoterpenoid & Fumigant toxicity against the adults of S. granaries [91]. \\
\hline$\beta$-Elemene & Cyclic sesquiterpene & Contact toxicity against D. melanogaster [99]. \\
\hline$\beta$-Eudesmol & Bicyclic sesquiterpenoid & Contact toxicity against $D$. melanogaster [99]. \\
\hline$\beta$-Pinene & Bicyclic monoterpene & Fumigant toxicity against the adults of S. granaries [91]. \\
\hline$\gamma$-Terpinene & Cyclic monoterpene & Larvicidal and pupicidal activity against C. quinquefasciatus [89]. \\
\hline$\varrho$-Cymene & Cyclic monoterpene & Larvicidal and pupicidal activity against C. quinquefasciatus [89]. \\
\hline
\end{tabular}




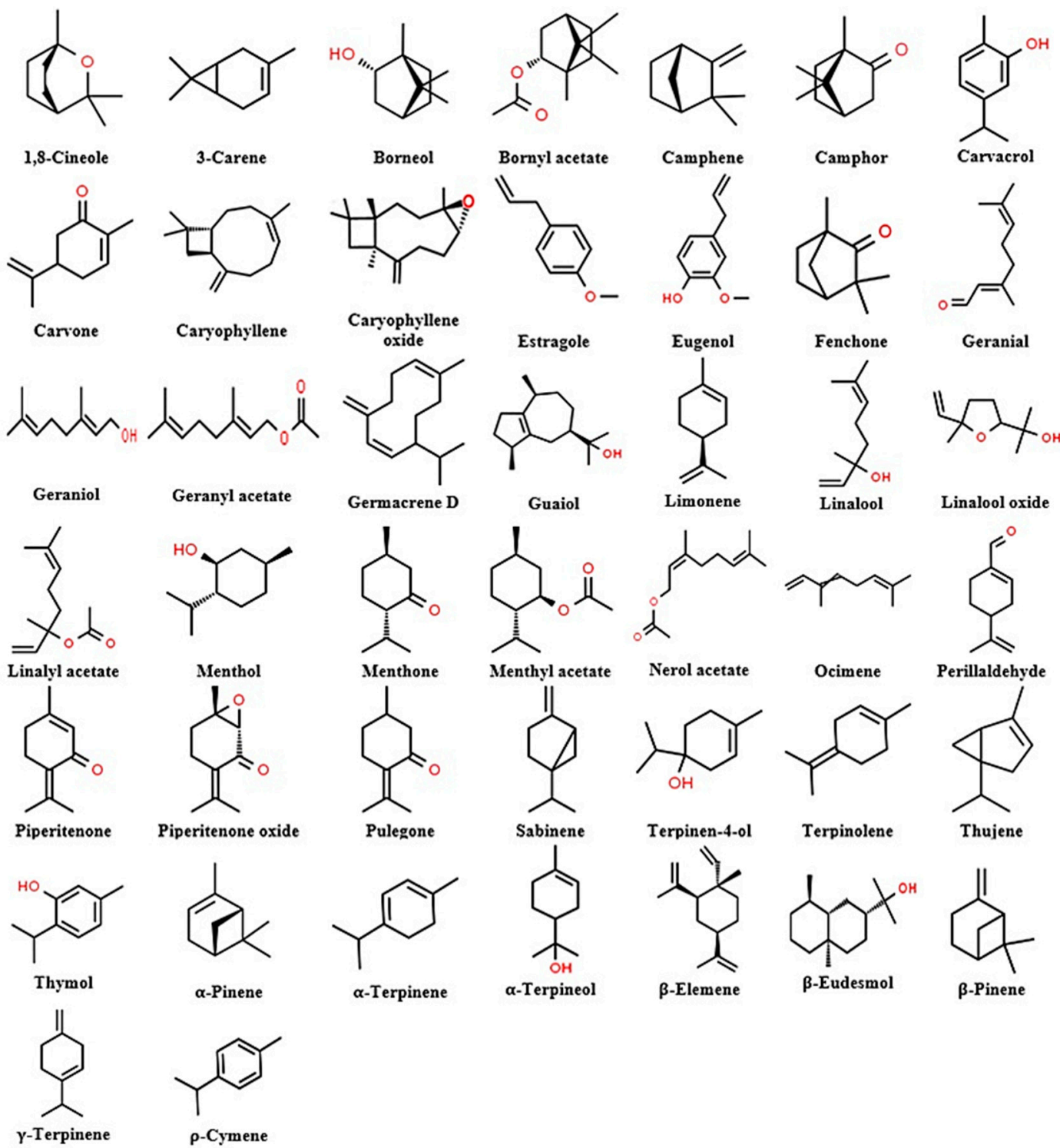

Figure 1. Chemical structure of main components identified in the essential oils of the Lamiaceae plant family.

Table 3 summarizes the bioactivity of the main components identified in the essential oils of Lamiaceae as a pesticide agent against insect pests. It has been found that the monoterpenoids had more fumigant toxicity than monoterpenes against the maize weevil, Sitophilus zeamais Motschulsky (Coleoptera: Curculionidae) [90]. The ketone, aldehyde (such as camphor, carvone, fenchone, and menthone), and epoxide (such as 1,8-cineole and limonene oxide) derivatives of monoterpenoids have also been found to be more toxic than alcohol and ester groups (such as borneol, linalool, and menthol) [90]. The essential oil of Salvia leriifolia Benth (Lamiaceae) showed the highest insecticidal activity as fumigant and contact agents against adults of C. maculatus, S. oryzae, and T. castaneum [100]. It was indicated that among eight terpenes including 1,8-cineole, carvacrol, eugenol, menthone, linalool, limonene, $\beta$-pinene, and $\alpha$-pinene, the cyclic monoterpenoids carvacrol and menthone had the most fumigant toxicity against the cowpea weevil, C. maculatus [101]. In another study, the fumigant and contact toxicities of eugenol (a phenylpropanoid), $\varrho$-cymene and $\alpha$-pinene (monoterpenes), and menthone, $\alpha$-terpinene, and terpinen-4-ol (monoterpenoids) were evaluated against T. castaneum adults. Terpinen-4-ol and $\alpha$-terpinene as cyclic terpenes had the most fumigant toxicity followed by menthone, $\varrho$-cymene, $\alpha$-pinene, and eugenol [96]. In contrast, eugenol was the most toxic compound 
in the contact bioassay. The fumigant toxicity of some essential oils' components was evaluated against bed bugs (Cimex lectularius L.) and it was found that cyclic monoterpenoids thymol and carvacrol had much more fumigant toxicity than bicyclic monoterpenoids camphor and 1,8-cineole, cyclic monoterpene limonene, bicyclic monoterpene $\alpha$-pinene, and phenylpropanes cinnamaldehdye, citronellic acid, eugenol and methyl eugenol [93]. Consequently, although the high insecticidal effects of monoterpenes, monoterpenoids, sesquiterpenes, sesquiterpenoids, and phenylpropanes has been reported, on the one hand, the monoterpenoids, especially cyclic monoterpenoids, showed the most toxic effects. On the other hand, minor structural differences cause major alterations in the toxic effects. However, susceptibility of the considered pests can be affected by the synergistic effects of other minor components [102].

Apart from insecticidal activity, the acaricidal efficacy of essential oils extracted from some Lamiaceae species have also been reported. The acaricidal effects of the essential oils of $S$. hortensis, Mentha pulegium L., Mentha viridis L., R. officinalis, and Z. multiflora was demonstrated against Tetranychus turkestani Ugarov and Nikolskii (Acari: Tetranychidae) [41]. Some of the constituents of R. officinalis essential oil were toxic against Tetranychus urticae Koch. (Acari: Tetranychidae) on bean and tomato plants. However, a synergistic effect among the active and inactive constituents was observed when they were mixed with each other [103].

Since larva is the damaging stage of insects, evaluating the larvicidal effect of essential oils is of great importance. For example, the larvicidal potential of essential oils of different Lamiaceae species has been reported in literature studies. The oil of Mentha piperita L. (Lamiaceae) was found to be an effective larvicidal agent against the housefly, Musca domestica (L.) (Diptera: Muscidae) [104]. The essential oil of $M$. piperita had higher larvicidal pupicidal than M. citrata Ehrh oil in contact and fumigant applications against $M$. domestica [105]. Similar results were obtained by the essential oil of M. piperita which had the most promising larvicidal against Anopheles stephensi Liston and Aedes aegypti L. (Diptera: Anophelinae) among 25 tested plant essential oils [106]. The larvicidal effects of M. piperita essential oil with a high quantity of bioactive monoterpenes were also reported on the $M$. domestica and An. stephensi larvae [107]. In other research with pure components, larvicidal effects of fifty constituents from terpene, terpenoid, and phenylpropanoid groups against Culex quinquefasciatus Say were assessed and it was demonstrated that carvacrol and thymol as cyclic monoterpenoids were the most toxic against larvae among all tested components [89].

Most of the Lamiaceae essential oils also have high repellent activity toward insects. For example, the essential oils of M. piperita and M. citrata showed effective repellency against $M$. domestica populations [104]. The repellent effect of essential oils extracted from Salvia dorisiana Standl, S. longifolia Nutt, and S. sclarea were reported against Aedes albopictus (Diptera:Culicidae) [108]. Ephestia kuehniella (Zeller) (Lepidoptera: Pyralidae) and Plodia interpunctella (Hübner) (Lepidoptera: Pyralidae) were also significantly repelled by Thymus daenensis Celak essential oil [109]. The essential oil of M. pulegium caused high repellent activity against the adults of T. castaneum and Lasioderma serricorne (F.) (Coleoptera: Anobiidae) [110]. Furthermore, substantial repellency of M. piperita essential oil on M. domestica has been reported which was higher than Eucalyptus globulus Labill and Citrus sinensis (L.) Osbeck essential oils [111].

\section{Mode of Pesticidal Action}

The mechanism of action of Lamiaceae essential oils and their components on pests is not completely recognized but, based on their diverse lethal and sublethal effects, it is obvious that these natural agents affect in different ways. The difference in the pesticidal potential of these agents could also be related to differences in their structures. For example, the higher toxicity of oxygenated monoterpenes as compared with the non-oxygenated ones could be due to the different structures of these components. Furthermore, according to recent findings, different physiological and behavioral modes of action of essential oils and their components have been reported. For example, inhibition of adenosine triphosphatases (ATPases), acetylcholinesterase (AChE) and butyrylcholinesterase 
(BuChE) [76,96], and distribution in the octopamine and gamma-aminobutyric acid receptors (GABArs) have been documented [112]. Given that octopamine receptors are invertebrates-specific, the use of essential oils in pest management, with this mode of action, can be considered to be safe bioagents for mammals [112]. Some other studies revealed that they can diminish esterase and glutathione S-transferases (GSTs) activities and total carbohydrate, lipid, and protein contents in the pests [73,113]. Detoxifying enzymes such as esterase and glutathione S-transferases have a significant effect on pest resistance before pesticides. Consequently, impairing the function of such enzymes can reduce the likelihood of pest resistance to essential oils [114]. Furthermore, histological changes in the epithelial cells of insects' midguts [115], and even a diminution in the respiration rate of pests have also been reported [116]. Generally, because of the wide pesticidal effects and several modes of action of the essential oils and their derivatives, pests have very few changes to resistant before these safe agents, and therefore they are very valuable in pest management strategies.

\section{Conclusions}

The overuse of synthetic chemicals in pest management programs has caused several side effects, such as contamination of drinking water; residues on food; acute or chronic negative effects on mammals and non-target organism including bird, bees, parasitoids, and predators; and the development of pest resistance. Due to this circumstance, researchers have focused on the application of plant-derived essential oils from different plant genera and families in recent years. Although the pesticidal properties of essential oils extracted from different species of Apiaceae, Lamiaceae, Myrtaceae, Rutaceae, Verbenaceae, and Zingiberaceae families have been recognized, the present review focused on the Lamiaceae species based on their availability and diversity. Along with these advantages, plant essential oils generally are nontoxic to mammals and other vertebrates. Furthermore, based on their multiple modes of action, development of pests' resistance against them is very low. Consequently, the Lamiaceae plant essential oils and their components with a wide range of lethal and sublethal effects against different damaging insects and mites in the field, greenhouse and storage conditions, have great potential in pests' management strategies and are considered to be safe, available, and eco-friendly alternatives to the synthetic chemicals. Indeed, the most important issue to be considered for the application of essential oils is their rapid degradation under the influence of air and light, which could be overcome by encapsulation or controlled release techniques. Briefly, the essential oils and their components, as core materials, are protected from adverse environmental factors in these techniques. Emulsifying the essential oils and components through adjuvants is another solution to improve pesticidal efficiency. However, their direct and indirect effects on the other non-target organisms such as honeybees and natural biocontrol agents and the economic aspects must be assessed before commercialization.

Author Contributions: Conceptualization, A.E. and M.Z.; methodology, A.E.; validation, A.E., M.Z., and F.P.; writing-original draft preparation, A.E.; writing—review and editing, A.E., M.Z., and F.P..; supervision, A.E.; funding acquisition, F.P. All authors have read and agreed to the published version of the manuscript.

Funding: This research received no external funding.

Acknowledgments: This research was supported by the University of Mohaghegh Ardabili, Ardabil, Iran. This study was also partially supported by the research project It@cha, PON 01_00625 “Ricerca e Competività (Scientific coordinator Franco Palla)".

Conflicts of Interest: The authors declare no conflict of interest.

\section{References}

1. Damalas, C.A.; Eleftherohorinosm, I.G. Pesticide exposure, safety issues, and risk assessment indicators. Int. J. Environ. Res. Public Health 2011, 8, 1402-1419. [CrossRef]

2. Loddé, B.; Lucas, D.; Letort, J.; Jegaden, D.; Pougnet, R.; Dewitte, J. Acute phosphine poisoning on board a bulk carrier: Analysis of factors leading to a fatal case. J. Occup. Med. Toxicol. 2015, 10, 10. 
3. Zikankuba, V.L.; Mwanyika, G.; Ntwenya, J.E.; James, A. Pesticide regulations and their malpractice implications on food and environment safety. Cogent Food Agric. 2019, 5, 1601544. [CrossRef]

4. Seiber, J.N.; Coats, J.; Duke, S.O.; Gross, A.D. Biopesticides: State of the art and future opportunities. J. Agric. Food Chem. 2014, 62, 11613-11619. [CrossRef] [PubMed]

5. Pichersky, E.; Gershenzon, J. The formation and function of plantvolatiles: Perfumes for pollinator attraction and defense. Curr. Opin. Plant Biol. 2002, 5, 237-243. [CrossRef]

6. Bakkali, F.; Averbeck, S.; Averbeck, D.; Idaomar, M. Biological effects of essential oils-A review. Food Chem. Toxicol. 2008, 46, 446-475. [CrossRef] [PubMed]

7. Regnault-Roger, C.; Vincent, C.; Arnason, J.T. Essential oils in insect control: Low-risk products in a high-stakes world. Annu. Rev. Entomol. 2012, 57, 405-424. [CrossRef]

8. Isman, M.B.; Grieneisen, M.L. Botanical insecticide research: Many publications, limited useful data. Trends Plant Sci. 2014, 19, 140-145. [CrossRef]

9. Ebadollahi, A.; Jalali-Sendi, J. A review on recent research results on bio-effects of plant essential oils against major Coleopteran insect pests. Toxin Rev. 2015, 34, 76-91. [CrossRef]

10. Francikowski, J.; Baran, B.; Cup, M.; Janiec, J.; Krzyzowski, M. Commercially available essential oil formulas as repellents against the stored-product pest Alphitobius diaperinus. Insects 2019, 10,96. [CrossRef]

11. Basaid, K.; Chebli, B.; Mayad, E.H.; Furze, J.N.; Bouharroud, R.; Krier, F.; Barakate, M.; Paulitz, T. Biological activities of essential oils and lipopeptides applied to control plant pests and diseases: A review. Int. J. Pest Manag. 2020. [CrossRef]

12. Rotolo, V.; De Caro, M.L.; Giordano, A.; Palla, F. Solunto archaeological park in Sicily: Life under tesserae. Flora Mediterr. 2018, 28, 233-245.

13. Palla, F.; Bruno, M.; Mercurio, F.; Tantillo, A.; Rotolo, V. Essential oil as natural biocides in conservation of cultural heritage. Molecules 2020, 25, 730. [CrossRef] [PubMed]

14. Ebadollahi, A. Essential oils isolated from Myrtaceae family as natural insecticides. Ann. Rev. Res. Biol. 2013, 3, 148-175.

15. Singh, P.; Pandey, A.K. Prospective of essential oils of the genus Mentha as biopesticides: A review. Front. Plant Sci. 2018, 9, 1295. [CrossRef]

16. Hernández-Carlos, B.; Gamboa-Angulo, M. Insecticidal and nematicidal contributions of Mexican flora in the search for safer biopesticides. Molecules 2019, 24, 897. [CrossRef]

17. Isman, M.B.; Miresmailli, S.; Machial, C. Commercial opportunities for pesticides based on plant essential oils in agriculture, industry and consumer products. Phytochem. Rev. 2011, 10, 197-204. [CrossRef]

18. Rasooli, I.; Gachkar, L.; Yadegari, D.; Bagher-Rezaei, M.; Taghizadeh, M.; Alipoor-Astaneh, S. Chemical and biological characteristics of Cuminum cyminum and Rosmarinus officinalis essential oils. Food Chem. 2007, 102, 898-904.

19. Cheng, S.S.; Chua, M.T.; Chang, E.H.; Huang, C.G.; Chen, W.J.; Chang, S.T. Variations in insecticidal activity and chemical compositions of leaf essential oils from Cryptomeria japonica at different ages. Bioresour. Technol. 2009, 100, 465-470. [CrossRef]

20. Ben Jemâa, J.M.; Tersim, N.; Toudert, K.T.; Khouj, M.L. Insecticidal activities of essential oils from leaves of Laurus nobilis L. from Tunisia, Algeria and Morocco, and comparative chemical composition. J. Stored Prod. Res. 2012, 48, 97-104.

21. Rahimzadeh, S.; Sohrabi, Y.; Heidari, G.; Pirzad, A.; Ghassemi Golezani, K. Effect of bio-fertilizers on the essential oil yield and components isolated from Dracocephalum moldavica L. using nanoscale injection method. J. Essent. Oil Bear. Plants 2016, 19, 529-541. [CrossRef]

22. Theis, N.; Lerdau, M. The evolution of function in plant secondary metabolites. Int. J. Plant Sci. 2003, 164, 93-102. [CrossRef]

23. Tholl, D. Terpene synthases and the regulation, diversity and biological roles of terpene metabolism. Curr. Opin. Plant Biol. 2006, 9, 297-304. [CrossRef] [PubMed]

24. Pavela, R.; Benelli, G. Essential oils as ecofriendly biopesticides? Challenges and constraints. Trends Plant Sci. 2016, 21, 1000-1007. [CrossRef] [PubMed]

25. Rotolo, V.; Barresi, G.; Di Carlo, E.; Giordano, A.; Lombardo, G.; Crimi, E.; Costa, E.; Bruno, M.; Palla, F. Plant extracts as green potential strategies to control the biodeterioration of cultural heritage. Int. J. Conserv. Sci. 2016, 7, 839-846. 
26. Isman, M.B. Botanical insecticides, deterrents, and repellents in modern agriculture and an increasingly regulated world. Ann. Rev. Entomol. 2006, 51, 45-66. [CrossRef] [PubMed]

27. Burt, S. Essential oils: Their antibacterial properties and potential applications in foods-A review. Int. J. Food Microbiol. 2004, 94, 223-253. [CrossRef]

28. Campos, E.V.R.; Proença, P.L.F.; Oliveira, J.L.; Bakshi, M.; Abhilash, P.C.; Fraceto, L.F. Use of botanical insecticides for sustainable agriculture: Future perspectives. Ecol. Indic. 2019, 105, 483-495. [CrossRef]

29. Rajendran, S.; Sriranjini, V. Plant products as fumigants for stored product insect control. J. Stored Prod. Res. 2008, 44, 126-135. [CrossRef]

30. Bahrami, R.; Kocheili, F.; Ziaee, M. Fumigant toxicity and persistence of essential oils from asafetida, geranium, and walnut on adults of Rhyzopertha dominica (Col.: Bostrichidae). Toxin Rev. 2016, 35, 63-68. [CrossRef]

31. Pavela, R. Insecticidal properties of several essential oils on the house fly (Musca domestica L.). Phytother. Res. 2008, 22, 274-278. [CrossRef] [PubMed]

32. Miresmailli, S.; Isman, M.B. Botanical insecticides inspired by plant-herbivore chemical interactions. Trends Plant Sci. 2014, 19, 29-35. [CrossRef] [PubMed]

33. Harley, R.M.; Atkins, S.; Budantsev, A.L.; Cantino, P.D.; Conn, B.J.; Grayer, R.J.; Harley, M.M.; de Kok, P.J.; Krestovskaja, T.V.; Morales, R.; et al. Labiatae. In The Families and Genera of Vascular Plants, 1st ed.; Kubitzki, K., Kadereit, J.W., Eds.; Springer: Berlin/Heidelberg, Germany, 2004; Volume 7, pp. 167-275.

34. Carović-Stanko, K.; Petek, M.; Grdiša, M.; Pintar, J.; Bedeković, D.; Herak Ćustić, M.; Satovic, Z. Medicinal plants of the family Lamiaceae as functional foods-A review. Czech J. Food Sci. 2016, 34, 377-390. [CrossRef]

35. Ozkan, M. Glandular and eglandular hairs of Salvia recognita Fisch. \& Mey. (Lamiaceae) in Turkey. Bangladesh J. Bot. 2008, 37, 93-95.

36. Raja, R.R. Medicinally potential of plant of Labiatae (Lamiaceae) family: An overview. Res. J. Med. Plants 2012, 9, 203-213. [CrossRef]

37. Mamadalieva, N.Z.; Akramov, D.K.; Ovidi, E.; Tiezzi, A.; Nahar, L.; Azimova, S.S.; Sarker, S.D. Aromatic medicinal plants of the Lamiaceae family from Uzbekistan: Ethnopharmacology, essential oils composition, and biological activities. Medicines 2017, 4, 8. [CrossRef]

38. Park, B.S.; Choi, W.S.; Kim, J.H.; Kim, K.H.; Lee, S.E. Monoterpenes from thyme (Thymus vulgaris) as potential mosquito repellents. J. Am. Mosq. Control Assoc. 2005, 21, 80-83. [CrossRef]

39. Park, I.; Kim, J.N.; Lee, Y.; Lee, S.; Ahn, Y.; Shin, S. Toxicity of plant essential oils and their components against Lycoriella ingenua (Diptera: Sciaridae). J. Econ. Entomol. 2008, 101, 139-144. [CrossRef]

40. Rozman, V.; Kalinovic, I.; Korunic, Z. Toxicity of naturally occurring compounds of Lamiaceae and Lauraceae to three stored-product insects. J. Stored Prod. Res. 2007, 43, 349-355. [CrossRef]

41. Zandi-Sohani, N.; Ramezani, L. Evaluation of five essential oils as botanical acaricides against the strawberry spider mite Tetranychus turkestani Ugarov and Nikolskii. Int. Biodeterior. Biodegrad. 2015, 98, 101-106. [CrossRef]

42. Ebadollahi, A. Chemical constituents and toxicity of essential oil from Agastache foeniculum (Pursh) Kuntze against two stored-product insect pests. Chil. J. Agric. Res. 2011, 71, 212-217. [CrossRef]

43. Conti, B.; Canale, A.; Cioni, P.L.; Flamini, G. Repellence of essential oils from tropical and Mediterranean Lamiaceae against Sitophilus zeamais. Bull. Insectol. 2010, 63, 197-202.

44. Ebadollahi, A.; Jalali Sendi, J.; Aliakbar, A.; Razmjou, J. Chemical composition and acaricidal effects of essential oils of Foeniculum vulgare Mill. (Apiales: Apiaceae) and Lavandula angustifolia Miller (Lamiales: Lamiaceae) against Tetranychus urticae Koch (Acari: Tetranychidae). Psyche 2014. [CrossRef]

45. Cosimi, S.; Rossi, E.; Cioni, P.L.; Canale, A. Bioactivity and qualitative analysis of some essential oils from Mediterranean plants against stored-product pests: Evaluation of repellency against Sitophilus zeamais Motschulsky, Cryptolestes ferrugineus (Stephens) and Tenebrio molitor (L.). J. Stored Prod. Res. 2009, 45, 125-132. [CrossRef]

46. Gonzalez-Coloma, A.; Martin-Benito, D.; Mohamed, N.; García-Vallejo, M.C.; Soria, A.C. Antifeedant effects and chemical composition of essential oils from different populations of Lavandula luisieri L. Biochem. Syst. Ecol. 2006, 34, 609-616. [CrossRef]

47. Ebadollahi, A.; Safaralizadeh, M.H.; Pourmirza, A.A. Fumigant toxicity of Lavandula stoechas L. oil against three insect pests attacking stored products. J. Plant Prot. Res. 2010, 50, 56-60. [CrossRef] 
48. Caballero-Gallardo, K.; Olivero-Verbel, J.; Stashenko, E.E. Repellent activity of essential oils and some of their individual constituents against Tribolium castaneum Herbst. J. Agric. Food Chem. 2011, 59, 1690-1696. [CrossRef]

49. Jeon, Y.-J.; Lee, H.-S. Chemical composition and acaricidal activities of essential oils of Litsea cubeba Fruits and Mentha arvensis leaves against house dust and stored food mites. J. Essent. Oil Bear. Plants 2016, 19, 1721-1728. [CrossRef]

50. Koliopoulos, G.; Pitarokili, D.; Kioulos, E.; Michaelakis, A.; Tzakou, O. Chemical composition and larvicidal evaluation of Mentha, Salvia, and Melissa essential oils against the West Nile virus mosquito Culex pipiens. Parasitol. Res. 2010, 107, 327-335. [CrossRef]

51. Mohamed, M.I.E.; Abdelgaleil, A.M.S. Chemical composition and insecticidal potential of essential oils from Egyptian plants against Sitophilus oryzae (L.) (Coleoptera: Curculionidae) and Tribolium castaneum (Herbst) (Coleoptera: Tenebrionidae). Appl. Entomol. Zool. 2008, 43, 599-607. [CrossRef]

52. Ebadollahi, A.; Davari, M.; Razmjou, J.; Naseri, B. Separate and combined effects of Mentha piperata and Mentha pulegium essential oils and a pathogenic fungus Lecanicillium muscarium against Aphis gossypii (Hemiptera: Aphididae). J. Econ. Entomol. 2017, 110, 1025-1030. [CrossRef] [PubMed]

53. Ebadollahi, A.; Ashrafi Parchin, R.; Farjaminezhad, M. Phytochemistry, toxicity and feeding inhibitory activity of Melissa officinalis L. essential oil against a cosmopolitan insect pest; Tribolium castaneum Herbst. Toxin Rev. 2016, 35, 77-82. [CrossRef]

54. Kerdchoechuen, O.; Laohakunjit, N.; Singkornard, S.; Matta, F.B. Essential oils from six herbal plants for biocontrol of the maize weevil. HortScience 2010, 45, 592-598. [CrossRef]

55. Al-Assiuty, B.A.; Nenaah, G.E.; Ageba, M.E. Chemical profile, characterization and acaricidal activity of essential oils of three plant species and their nanoemulsions against Tyrophagus putrescentiae, a stored-food mite. Exp. Appl. Acarol. 2019, 79, 359-376. [CrossRef]

56. Rajamma, A.J.; Dubey, S.; Sateesha, S.B.; Tiwari, S.N.; Ghosh, S.K. Comparative larvicidal activity of different species of Ocimum against Culex quinquefasciatus. Nat. Prod. Res. 2011, 25, 1916-1922. [CrossRef]

57. Tozlu, E.; Cakir, A.; Kordali, S.; Tozlu, G.; Ozer, H.; Akcine, T.A. Chemical compositions and insecticidal effects of essential oils isolated from Achillea gypsicola, Satureja hortensis, Origanum acutidens and Hypericum scabrum against broad bean weevil (Bruchus dentipes). Sci. Hortic. 2011, 130, 9-17. [CrossRef]

58. Ramzi, H.; Ismaili, M.R.; Aberchane, M.; Zaanoun, S. Chemical characterization and acaricidal activity of Thymus satureioides C. \& B. and Origanum elongatum E. \& M. (Lamiaceae) essential oils against Varroa destructor Anderson \& Trueman (Acari: Varroidae). Ind. Crop Prod. 2017, 108, 201-207.

59. Khalfi, O.; Sahraoui, N.; Bentahar, F.; Boutekedjiret, C. Chemical composition and insecticidal properties of Origanum glandulosum (Desf.) essential oil from Algeria. J. Sci. Food Agric. 2008, 88, 1562-1566. [CrossRef]

60. Alkan, M. Chemical composition and insecticidal potential of different Origanum spp. (Lamiaceae) essential oils against four stored product pests. Turk. Entomol. Derg. 2020, 44, 149-163. [CrossRef]

61. Yildirim, E.; Kordali, S.; Yazici, G. Insecticidal effects of essential oils of eleven plant species from Lamiaceae on Sitophilus granarius (L.) (Coleoptera: Curculionidae). Rom. Biotechnol. Lett. 2011, 16, 6702-6709.

62. You, C.; Wang, Y.; Zhang, W.; Yang, K.; Wu, Y.; Geng, Z.; Chen, H.; Jiang, H.; Du, S.; Deng, Z.; et al. Chemical constituents and biological activities of the Purple Perilla essential oil against Lasioderma serricorne. Ind. Crop Prod. 2014, 61, 331-337. [CrossRef]

63. Arabi, F.; Moharramipou, S.; Sefidkon, F. Chemical composition and insecticidal activity of essential oil from Perovskia abrotanoides (Lamiaceae) against Sitophilus oryzae (Coleoptera: Curculionidae) and Tribolium castaneum (Coleoptera: Tenebrionidae). Int. J. Trop. Insect. Sci. 2008, 28, 144-150. [CrossRef]

64. Chu, S.S.; Liu, Q.Z.; Jiang, G.H.; Liu, Z.L. Chemical composition and insecticidal activity of the essential oil derived from Phlomis umbrosa against two grain storage insects. J. Essent. Oil Bear. Plants 2013, 16, 51-58. [CrossRef]

65. Sharififard, M.; Sharififard, F.; Safdari, A.; Siahpoush, H.; Kassiri. A. Evaluation of some plant essential oils against the brown-banded cockroach, Supella longipalpa (Blattaria: Ectobiidae): A mechanical vector of human pathogens. J. Arthropod-Borne Dis. 2016, 10, 528-537. [PubMed]

66. Ali, A.; Tabanca, N.; Demirci, B.; Blythe, E.K.; Ali, Z.; Can Baser, H.; Khan, I.A. Chemical composition and biological activity of four Salvia essential oils and individual compounds against two species of mosquitoes. J. Agric. Food Chem. 2015, 63, 447-456. [CrossRef] 
67. Nouri-Ganbalani, G.; Ebadollahi, A.; Nouri, A. Evaluation of chemical composition and toxicity of two essential oils against adults of Tribolium castaneum and Callosobruchus maculatus. Plant Protect. 2015, 38, 103-113.

68. Ebadollahi, A.; Jalali Sendi, J.; Aliakbar, A.; Razmjou, J. Acaricidal activities of essential oils of Satureja hortensis (L.) and Teucrium polium (L.) against two spotted spider mite, Tetranychus urticae Koch (Acari: Tetranychidae). Egypt J. Biol. Pest Control 2015, 25, 171-176.

69. Taghizadeh-Saroukolai, A.; Nouri-Ganbalani, G.; Rafiee-Dastjerdi, H.; Hadian, J. Antifeedant activity and toxicity of some plant essential oils to Colorado potato beetle, Leptinotarsa decemlineata Say (Coleoptera: Chrysomelidae). Plant Protect. Sci. 2014, 50, 207-216. [CrossRef]

70. Ayvaz, A.; Sagdic, O.; Karaborklu, S.; Ozturk, I. Insecticidal activity of the essential oils from different plants against three stored-product insects. J. Insect Sci. 2010, 10, 21. [CrossRef]

71. Ebadollahi, A.; Jalali Sendi, J.; Aliakbar, A. Efficacy of nanoencapsulated Thymus eriocalyx and Thymus kotschyanus essential oils by a mesoporous material MCM-41 against Tetranychus urticae (Acari: Tetranychidae). J. Econ. Entomol. 2017, 110, 2413-2420. [CrossRef]

72. Mahmoudvand, M.; Abbasipour, H.; Basij, M.; Hosseinpour, M.H.; Rastegar, F.; Nasiri, M.B. Fumigant toxicity of some essential oils on adults of some stored-product pests. Chil. J. Agric. Res. 2011, 71, 83-89. [CrossRef]

73. Ebadollahi, A.; Khosravi, R.; Jalali Sendi, J.; Mahboubi, M.; Kosari, A.A. Chemical composition of essential oil from Zhumeria majdae Rech. F. \& Wendelbo and its bioactivities against Tribolium castaneum Herbst (Tenebrionidae) larvae. J. Essent. Oil Bear. Plants 2014, 17, 824-831.

74. Matos, F.; Miguel, M.G.; Duarte, J.; Venncio, F.; Moiteiro, C.; Correia, A.I.D.; Figueiredo, A.C.; Barroso, J.G.; Pedro, L.G. Antioxidant capacity of the essential oils from Lavandula luisieri, L. stoechas subsp. lusitanica, L. stoechas subsp. lusitanica $x$ L. luisieri and L. viridis grown in Algarve (Portugal). J. Essent. Oil Res. 2009, 21, 327-336. [CrossRef]

75. Ogendo, J.O.; Kostyukovsky, M.; Ravid, U.; Matasyoh, J.C.; Deng, A.L.; Omolo, E.O.; Kariuki, S.T.; Shaaya, E. Bioactivity of Ocimum gratissimum L. oil and two of its constituents against five insect pests attacking stored food products. J. Stored Prod. Res. 2008, 44, 328-334. [CrossRef]

76. Özbek, H.; Güvenalp, Z.; Özek, T.; Sevindik, H.G.; Yuca, H.; Yerdelen, K.Ö.; Demirezer, L.Ö. Chemical composition, antioxidant and anticholinesterase activities of the essential oil of Origanum rotundifolium Boiss. from Turkey. Rec. Nat. Prod. 2017, 11, 485-490. [CrossRef]

77. Barazandeh, M.M. Volatile constituents of the oil of Salvia hydrangea DC. ex Benth. from Iran. J. Essent. Oil Res. 2011, 16, 20-21. [CrossRef]

78. Paknejadi, M.; Foroohi, F.; Yousefzadi, M. Antimicrobial activities of the essential oils of five Salvia species from Tehran province, Iran. J. Paramed. Sci. 2012, 3, 12-18.

79. Chizzola, R. Composition and variability of the essential oil of Salvia nemorosa (Lamiaceae) from the Vienna area of Austria. Nat. Prod. Commun. 2012, 7, 1671-1672. [CrossRef]

80. Eftekhar, F.; Raei, F.; Yousefzadi, M.; Nejad Ebrahimi, S.; Hadian, J. Antibacterial activity and essential oil composition of Satureja spicigera from Iran. Z. Naturforsch. 2009, 64, 20-24. [CrossRef]

81. Küçükbay, F.Z.; Kuyumcu, E.; Çelen, S.; Azaz, A.D.; Arabac1, T. Chemical composition of the essential oils of three Thymus taxa from Turkey with antimicrobial and antioxidant activities. Rec. Nat. Prod. 2014, 8, 110-120.

82. Taghizadeh-Sarikolaei, A.; Moharamipour, S.; Meshkatalsadat, M.H. Insecticidal properties of Thymus persicus essential oil against Tribolium castaneum and Sitophilus oryzae. J. Pest Sci. 2010, 83, 3-8.

83. Ceylan, O.; Ugur, A. Chemical composition and anti-biofilm activity of Thymus sipyleus Boiss. subsp. sipyleus Boiss. var. davisianus Ronniger essential oil. Arch. Pharm. Res. 2015, 38, 957. [CrossRef] [PubMed]

84. Saei-Dehkordi, S.S.; Tajik, H.; Moradi, M.; Khalighi-Sigaroodi, F. Chemical composition of essential oils in Zataria multiflora Boiss. from different parts of Iran and their radical scavenging and antimicrobial activity. Food Chem. Toxicol. 2010, 48, 1562-1567. [CrossRef] [PubMed]

85. Ludwiczuk, A.; Skalicka-Woźniak, K.; Georgiev, M.I. Terpenoids: Pharmacognosy; Academic Press: Boston, MA, USA, 2017; pp. 233-266.

86. Speight, J.G. Hydrocarbons from Biomass. In Handbook of Industrial Hydrocarbon Processes, 1st ed.; Speight, J.G., Ed.; Gulf Professional Publishing: Houston, TX, USA, 2011; pp. 241-279.

87. Mewalal, R.; Rai, D.K.; Kainer, D.; Chen, F.; Külheim, C.; Peter, G.F.; Tuskan, G.A. Plant-derived terpenes: A feedstock for specialty biofuels. Trends Biotechnol. 2017, 35, 227-240. [CrossRef] [PubMed] 
88. Carvalho, A.A.; Andrade, L.N.; de Sousa, É.B.V.; de Sousa, D.P. Antitumor phenylpropanoids found in essential oils. Biomed. Res. Int. 2015, 2015, 392674. [CrossRef]

89. Andrade-Ochoa, S.; Correa-Basurto, J.; Rodriguez-Valdez, L.M.; Sanchez-Torres, L.E.; Nogueda-Torres, B.; Nevarez-Moorillon, G.V. In vitro and in silico studies of terpenes, terpenoids and related compounds with larvicidal and pupicidal activity against Culex quinquefasciatus Say (Diptera: Culicidae). Chem. Cent. J. 2018, 12, 53. [CrossRef]

90. Yildirim, E.; Emsen, B.; Kordali, S. Insecticidal effects of monoterpenes on Sitophilus zeamais Motschulsky (Coleoptera: Curculionidae). J. Appl. Bot. Food Qual. 2013, 86, 198-204.

91. Kordali, Ş.; Usanmaz, A.; Bayrak, N.; Çakır, A. Fumigation of volatile monoterpenes and aromatic compounds against adults of Sitophilus granarius (L.) (Coleoptera: Curculionidae). Rec. Nat. Prod. 2017, 11, 362-373.

92. Yi, C.G.; Hieu, T.T.; Lee, S.H.; Choi, B.R.; Kwon, M.; Ahn, Y.J. Toxicity of Lavandula angustifolia oil constituents and spray formulations to insecticide-susceptible and pyrethroid- resistant Plutella xylostella and its endoparasitoid Cotesia glomerata. Pest Manag. Sci. 2016, 76, 1202-1210. [CrossRef]

93. Gaire, S.; Scharf, M.E.; Gondhalekar, A.D. Toxicity and neurophysiological impacts of plant essential oil components on bed bugs (Cimicidae: Hemiptera). Sci. Rep. 2019, 9, 3961. [CrossRef]

94. Cárdenas-Ortega, N.C.; González-Chávez, M.M.; Figueroa-Brito, R.; Flores-Macías, A.; Romo-Asunción, D.; Martínez-González, D.E.; Pérez-Moreno, V.; Ramos-López, M.A. Composition of the essential oil of Salvia ballotiflora (Lamiaceae) and its insecticidal activity. Molecules 2015, 20, 8048-8059. [CrossRef] [PubMed]

95. Yeom, H.J.; Jung, C.S.; Kang, J.S.; Kim, J.; Lee, J.H.; Kim, D.S.; Kim, H.S.; Park, P.S.; Kang, K.S.; Park, I.K. Insecticidal and acetylcholine esterase inhibition activity of Asteraceae plant essential oils and their constituents against adults of the German cockroach (Blattella germanica). J. Agric. Food Chem. 2015, 63, 2241-2248. [CrossRef] [PubMed]

96. Saad, M.M.G.; El-Deeb, D.A.; Abdelgaleil, S.A.M. Insecticidal potential and repellent and biochemical effects of phenylpropenes and monoterpenes on the red flour beetle, Tribolium castaneum Herbst. Environ. Sci. Pollut. Res. 2019, 26, 6801-6810. [CrossRef] [PubMed]

97. Sfara, V.; Zerba, E.N.; Alzogaray, R.A. Fumigant insecticidal activity and repellent effect of five essential oils and seven monoterpenes on first-instar nymphs of Rhodnius prolixus. J. Med. Entomol. 2009, 46, 511-515. [CrossRef] [PubMed]

98. Tripathi, A.K.; Prajapati, V.; Ahmad, A.; Aggarwal, K.K.; Khanuja, S.P. Piperitenone Oxide as toxic, repellent, and reproduction retardant toward malarial vector Anopheles stephensi (Diptera: Anophelinae). J. Med. Entomol. 2004, 41, 691-698. [CrossRef] [PubMed]

99. Chu, S.S.; Jiang, G.H.; Liu, Z.L. Insecticidal compounds from the essential oil of Chinese medicinal herb Atractylodes chinensis. Pest Manag. Sci. 2011, 67, 1253-1257. [CrossRef] [PubMed]

100. Hashemi, S.M.; Hosseini, B.; Estaji, A. Chemical composition and insecticidal properties of the essential oil of Salvia leriifolia Benth (Lamiaceae) at two developmental stages. J. Essent. Oil Bear. Plants 2013, 16, 806-816. [CrossRef]

101. Ajayi, O.E.; Appel, A.G.; Fadamiro, H.Y. Fumigation toxicity of essential oil monoterpenes to Callosobruchus maculatus (Coleoptera: Chrysomelidae: Bruchinae). J. Insects 2014. [CrossRef]

102. Papachristos, D.P.; Karamanoli, K.; Stamopoulos, D.C.; Menkissoglu-Spiroudi, U. The relationship between the chemical composition of three essential oils and their Insecticidal activity against Acanthoscelides obtectus (Say). Pest Manag. Sci. 2004, 60, 514-520. [CrossRef]

103. Miresmailli, S.; Bradbury, R.; Isman, M.B. Comparative toxicity of Rosmarinus officinalis L. essential oil and blends of its major constituents against Tetranychus urticae Koch (Acari: Tetranychidae) on two different host plants. Pest Manag. Sci. 2006, 62, 366-371. [CrossRef]

104. Kumar, P.; Mishra, S.; Malik, A.; Satya, S. Repellent, larvicidal and pupicidal properties of essential oils and their formulations against the housefly, Musca domestica. Med. Vet. Entomol. 2011, 25, 302-310. [CrossRef] [PubMed]

105. Kumar, P.; Mishra, S.; Malik, A.; Satya, S. Efficacy of Menthaxpiperita and Mentha citrata essential oils against housefly, Musca domestica L. Ind. Crop Prod. 2012, 39, 106-112. [CrossRef]

106. Manimaran, A.; Cruz, M.M.J.J.; Muthu, C.; Vincent, S.; Ignacimuthu, S. Larvicidal and knockdown effects of some essential oils against Culex quinquefasciatus Say, Aedes aegypti (L.) and Anopheles stephensi (Liston). Adv. Biosci. Biotechnol. 2012, 3, 855-862. [CrossRef] 
107. Chauhan, N.; Malik, A.; Sharma, S.; Dhiman, R.C. Larvicidal potential of essential oils against Musca domestica and Anopheles stephensi. Parasitol. Res. 2016, 115, 2223-2231. [CrossRef]

108. Conti, B.; Benelli, G.; Leonardi, M.; Afifi, F.U.; Cervelli, C.; Profeti, R.; Pistelli, L.; Canale, A. Repellent effect of Salvia dorisiana, S. longifolia, and S. sclarea (Lamiaceae) essential oils against the mosquito Aedes albopictus Skuse (Diptera: Culicidae). Parasitol. Res. 2012, 111, 291-299. [CrossRef]

109. Moazeni, N.; Khajeali, J.; Izadi, H.; Mahdian, K. Chemical composition and bioactivity of Thymus daenensis Celak (Lamiaceae) essential oil against two lepidopteran stored-product insects. J. Essent. Oil Res. 2014, 26, 118-124. [CrossRef]

110. Salem, N.; Bachrouch, O.; Sriti, J.; Msaada, K.; Khammassi, S.; Hammami, M.; Selmi, S.; Boushih, E.; Koorani, S.; Abderraba, M.; et al. Fumigant and repellent potentials of Ricinus communis and Mentha pulegium essential oils against Tribolium castaneum and Lasioderma serricorne. Int. J. Food Prop. 2017, 21, 2265-2275. [CrossRef]

111. Chauhan, N.; Malik, A.; Sharma, S. Repellency potential of essential oils against housefly, Musca domestica L. Environ. Sci. Poll. Res. 2018, 25, 4707-4714. [CrossRef]

112. Jankowska, M.; Rogalska, J.; Wyszkowska, J.; Stankiewicz, M. Molecular targets for components of essential oils in the insect nervous system-A Review. Molecules 2018, 23, 34. [CrossRef]

113. Ebadollahi, A.; Khosravi, R.; Jalali Sendi, J.; Mahboubi, M.; Kosari, A.A. Toxicity and physiological effects of essential oil from Agastache foeniculum (Pursh) Kuntze against Tribolium castaneum Herbst (Coleoptera: Tenebrionidae) larvae. Ann. Rev. Res. Biol. 2013, 3, 649-658.

114. Gunderson, M.P.; Nguyen, B.T.; Cervantes Reyes, J.C.; Holden, L.L.; French, J.; Smith, B.D.; Lineberger, C. Response of phase I and II detoxification enzymes, glutathione, metallothionein and acetylcholine esterase to mercury and dimethoate in signal crayfish (Pacifastacus leniusculus). Chemosphere 2018, 208, 749-756. [CrossRef] [PubMed]

115. Osman, S.E.I.; Swidan, M.H.; Kheirallah, D.A.; Nour, F.E. Histological effects of essential oils, their monoterpenoids and insect growth regulators on midgut, integument of larvae and ovaries of khapra beetle, Trogoderma granarium everts. J. Biol. Sci. 2016, 16, 93-101. [CrossRef]

116. Plata-Rueda, A.; Martínez, L.C.; Dos Santos, M.H.; Fernandes, F.L.; Wilcken, C.F.; Soares, M.A.; Serrao, J.E.; Zanuncio, J.C. Insecticidal activity of garlic essential oil and their constituents against the mealworm beetle, Tenebrio molitor Linnaeus (Coleoptera: Tenebrionidae). Sci. Rep. 2017, 7, 46406. [CrossRef] [PubMed] 